\title{
Deri ve yumuşak doku enfeksiyonları
}

\author{
Skin and soft tissue infections
}

\author{
Savaş Güner \\ Gaziantep Üniversitesi Tıp Fakültesi, Ortopedi ve Travmatoloji Anabilim Dalı, Gaziantep
}

Deri ve yumuşak doku enfeksiyonları, Amerika Birleşik Devletleri'nde enfeksiyon nedeniyle hastaneye başvuranların yaklaşık \%10'unu oluşturan, en yaygın bakteriyel enfeksiyonlar arasındadır. Deri ve yumuşak doku enfeksiyonları, sellülitten hayatı ve uzuvları tehdit eden nekrotizan fasiite kadar uzanan geniş bir yelpazede görülebilir. Deri ve yumuşak doku enfeksiyonları için çeşitli sınıflamalar olmakla birlikte evrensel olarak kabul edilen bir sınıflama sistemi bulunmamaktadır. Bu makalede deri ve yumuşak doku enfeksiyonları; nekrotizan ve nekrotizan olmayan deri ve yumuşak doku enfeksiyonları olarak iki ana başlık altında sunuldu.

Anahtar sözcükler: deri enfeksiyonları; yumuşak doku enfeksiyonları; tedavi

\begin{abstract}
Skin and soft tissue infections are among the most common bacterial infections that make up about $10 \%$ of hospital admissions for infections in the United States. Skin and soft tissue infections can range from cellulitis to necrotizing fasciitis that threaten life and limbs. Although there are various classifications for skin and soft tissue infections, there is no universally accepted classification system. In this article, necrotizing and non-necrotizing skin and soft tissue infections are presented under two main headings.
\end{abstract}

Key words: skin infections; soft tissue infections; treatment
D eri, iç organlar ile dış çevre arasında bir bariyer işlevi görür ve insan vücudunun en büyük organıdır. Dış ortamda bulunan birçok mikroorganizma ve toksik maddelerle sürekli ilişki durumundadır. Deri üç kısımdan oluşur (epidermis, dermis ve cilt altı yağ dokusu). Cilt altı yağ dokusunun altında fasya bulunur, fasya kas dokusu ile cilt altı dokuyu birbirinden ayırır. Deri travmalar ve mikroorganizmalara karşı bariyer işlevi görmesinin yanı sıra, immunolojik birçok fonksiyonu da beraberinde taşımaktadır. ${ }^{[1]}$ Deri ve yumuşak doku enfeksiyonları (DYDE), Amerika Birleşik Devletleri'nde enfeksiyon nedeniyle hastaneye başvuranların yaklaşık \%10'unu oluşturan, en yaygın bakteriyel enfeksiyonlar arasındadır. DYDE, sellülitten hayatı ve uzuvları tehdit eden nekrotizan fasiite kadar uzanan geniş bir yelpazede görülebilir. ${ }^{[2]}$

DYDE için çeşitli sınıflamalar olmakla birlikte evrensel olarak kabul edilen bir sınıflama sistemi bulunmamaktadır. DYDE'lerini etkilediği deri katmanına göre (Tablo 1) veya nekrotizan ve nekrotizan olmamasına göre yapılan sınıflama sıklıkla kullanılmaktadır (Tablo 2).[2] Bu makalede, nekrotizan ve nekrotizan olmayan DYDE olarak iki ana başlık altında sınıflandırarak sunuldu.

\section{NEKROTIZAN OLMAYAN DYDE’LER}

\section{Erizipel}

Halk arasında "yılancık" adı ile bilinir. Lenf sistemi tutulumu ağırlıktadır ve derinin yüzeyel dermis tabakasının etkilendiği bir enfeksiyondur. En sık alt ekstremitelerde ve yüzde görülür. Küçük çocuk ve ileri yaş grubunda daha sık gözlenir. Tutulum olan deri sağlam deriden keskin sınırlarla ayrılır. Lezyon parlak, ödemli, kırmızı renkli ve portakal kabuğu görünümündedir. Ağrı tabloya eşlik eder. ${ }^{[3]}$ Laboratuvar tetkiklerinde CRP, sedimentasyon artışı ve lökositoz görülür. Tedavide 7-10 gün süre ile intramusküler prokain penisilin ( $600.000 \mathrm{U} /$ gün) veya oral penisilin V (250-500 mg × 4), birinci kuşak sefalosporinler veya makrolidler kullanılabilir. ${ }^{[3]}$

- Illetişim adresi: Prof. Dr. Savaş Güner, Gaziantep Üniversitesi Tıp Fakültesi, Ortopedi ve Travmatoloji Anabilim Dalı, Gaziantep Tel: 0533 - 2433873 e-posta: gunersavas@gmail.com

- Geliş tarihi: 29 Mayıs $2020 \quad$ Kabul tarihi: 20 Temmuz 2020 
Tablo 1. Deri ve yumuşak doku enfeksiyonlarının etkilediği deri katmanına göre sınıflama ${ }^{[2]}$

\begin{tabular}{ll}
\hline Yumuşak doku enfeksiyonu & Etkilenen deri katmanı \\
\hline Erizipel & Yüzeyel dermis \\
Sellülit & Subkütan yağ dokusu \\
Impetigo & Epidermis \\
Fronkül & Kıl follikülleri \\
Karbonkül & Kıl follikülleri \\
Myozit & Kas \\
Gangren & Kas \\
Nekrotizan fasiit & Fasya
\end{tabular}

Tablo 2. Deri ve yumuşak doku enfeksiyonlarının nekrotizan ve nekrotizan olmamasına göre yapılan sınıflama ${ }^{2]}$

\begin{tabular}{ll}
\hline Nekrotizan olmayan DYDE & Nekrotizan DYDE \\
\hline Erizipel & Nekrotizan fasiit \\
Sellülit & Klostridiyal miyonekroz \\
İmpetigo & Fornier gangreni \\
Follikülit & \\
Fronkül & \\
Karbonkül & \\
\hline
\end{tabular}

DYDE: Deri ve Yumuşak Doku Enfeksiyonları

\section{Sellülit}

Yüzeyel dermis tabakası ve subkutan doku tutulumu mevcuttur. Tüm yaş gruplarında görülebilir. A grubu $\beta$-hemolitik streptokoklar ve S.aureus en sık etkendir. ${ }^{[4]}$ Ciltte ısı artışı, kızarıklık ve ödem görülür. Lezyon keskin sınır ile sağlam deriden ayrılmaz. Etkilenen ciltte bül (seröz sıvı ile doludur), vezikül (seröz sıvı ile doludur), peteşi ve ekimoz görülebilir. Sistemik bulgular (ateş, halsizlik, üşüme titreme) genellikle şiddetli değildir. ${ }^{[1,4]}$ Şişmanlık, geçirilmiş deri hasarları, venöz yetmezlik, lenfatik sistem tıkanıklığı, ciltte fissür ve ülser gibi cildin frajilitesini artıran, savunma mekanizmasını azaltan durumlarda sellülit daha kolay meydana gelir. Sellülit en sık alt ekstremitelerde görülür. ${ }^{[5]}$ Laboratuvarda CRP, sedimentasyon artışı ve lökositoz görülür. Sellülitte etkenin gösterilmesi çoğu zaman mümkün değildir. Kan kültürü \%95'in üzerinde negatiftir. Aspirasyon biyopsisi negatifliği ise \%60-95 arasındadır. ${ }^{[4]}$ Bu nedenle tedavide öncelikle stafilokok ve streptokoklara yönelik antibiyoterapi uygulanmalıdır (prokain penisilin G, ampisilin sulbaktam, amoksisilin klavulonik asit, klindamisin, birinci kuşak sefalosporinler 10-14 gün). Fakat farklı etyolojik ajan düşünüldüğü durumlarda (DM [Diabetes mellitus], hayvan-insan ısırığı, immunosupresyon vb.) etkeni izole etmek önemlidir. Sellülite neden olan altta yatan hastalıkların düzeltilmesi ile yeniden sellülit oluşumu (tekrarlayan sellülit atakları elefantiyazise neden olur) engellenebilir. ${ }^{[5]}$

\section{İmpetigo}

Yüzeyel deri enfeksiyonudur. Çocuk yaş grubunda sık görülür, bulaşıcıdır. A grubu streptokoklar ve S.aureus en sık etkendir. ${ }^{[2]}$ Streptokokların oluşturduğu kalın kabuklu lezyonlarla seyreden formuna impetigo kontagiosa, stafilokokların oluşturduğu büllerle seyreden formuna Impetigo bullosa adı verilir. Çoğunlukla vücudun açık bölgelerinde (el, kol, yüz gibi) görülür. Önce eritem oluşur daha sonra püstüle dönüşüp patlar. Altın sarısı kurutla iyileşir. Tedavide kurutların kaldırımasının ardından yaranın antiseptik solüsyonla temizlenip, topikal antibakteriyel pomat uygulanması sıklıkla yeterli olmaktadır. İnatçı olgularda benzatin penisilin (i.m., tek doz) veya oral penisilin V (10 gün) kullanılabilir. ${ }^{[5]}$

\section{Follikülit, Fronkül ve Karbonkül}

Follikülit; kıl follikülünün eritematöz, püstüllü enfeksiyonudur. Saçlı deri ve sakallı alanları sıklıkla tutar. Tedavide lezyonun serum fizyolojik ile temizlenmesi ve topikal antibiyotikli pomatların kullanılması genellikle yeterlidir. ${ }^{[6]}$

Follikülitin cilt ve cilt altı dokuya ilerlemesiyle oluşan enfeksiyona fronkül olarak adlandırılır. Çıban olarakda bilinir. En sık yüz, boyun ve kalçada görülür. Fronkül dermiste kırmızı, ağrılı bir nodül olarak başlar, apseleşir ve daha sonra cilt dışına drene olarak iyileşir. Tedavide lokal veya sistemik stafilokokkal etkinliği olan antibiyotikler (sefaleksin, kotrimaksazol, klindamisin ve makrolidler) kullanılır. Eğer fronkül büyükse cerrahi drenaj ve antibiyoterapi uygulanmalıdır. ${ }^{[2,6]}$

Birden fazla fronkülün bir arada görülmesi karbonkül olarak adlandırılır. Boyun, sırt ve bacaklarda sıklıkla gözlenir. Follikülit, fronkül ve karbonkülde en sık etken S.aureus'tur. Karbonküller daha derin dokularda görülür ve daha geniş yayılım gösterirler. Osteomiyelite neden olabilirler. Tedavide cerrahi drenaj, ıslak pansuman ve stafilokkal etkinliği olan sistemik antibiyotik tedavisi uygulanmalıdır (10-14 gün). ${ }^{[5]}$

\section{NEKROTIZAN DYDE'LER}

\section{Nekrotizan Fasiit}

Nekrotizan fasiit, cilt, cilt altı dokular ve fasyanın ilerleyici nekrozu ile seyreden bir enfeksiyondur. Cerrahi tedavi ve antibiyoterapiye rağmen mortalite \%6-76 arasında seyretmektedir. Daha çok erişkinlerde 


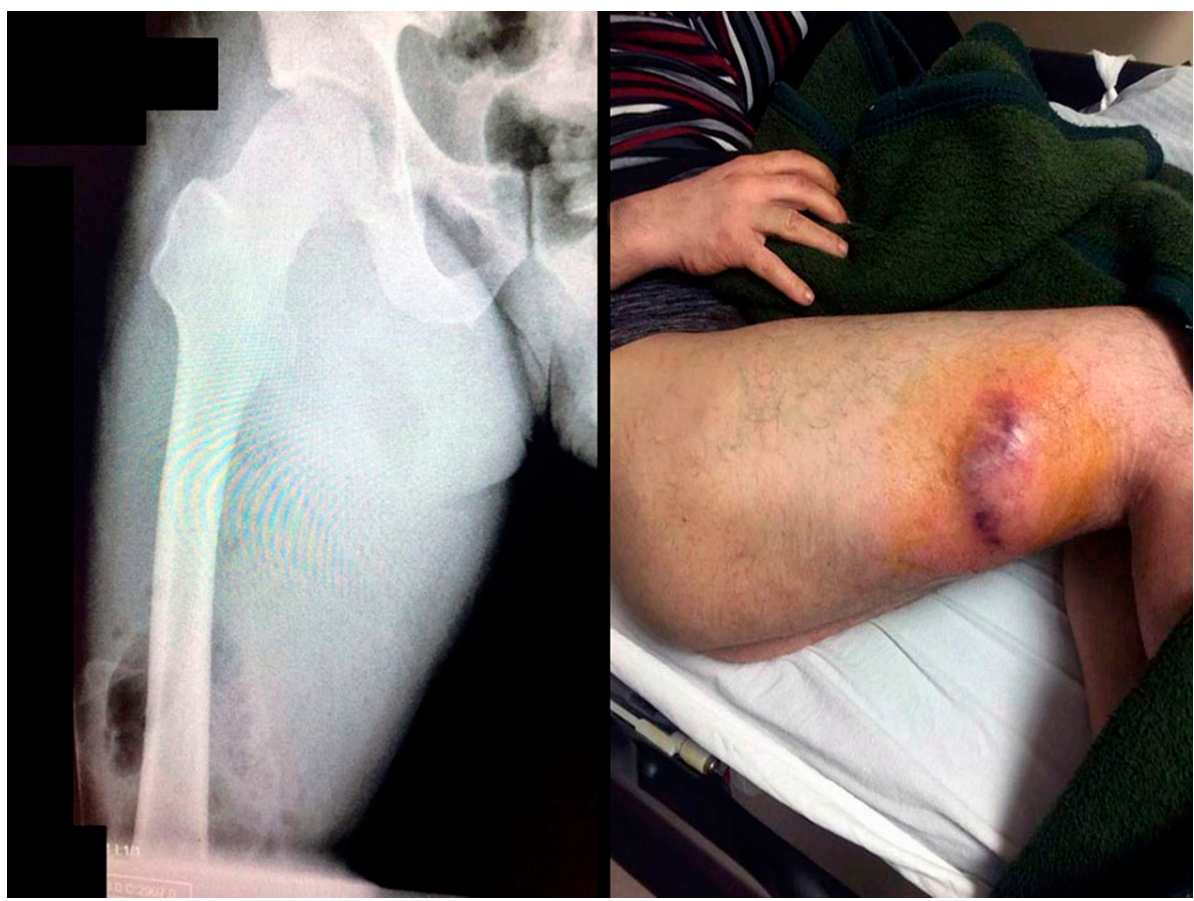

Şekil 1. Sağ uylukta nekrotizan fasiitin direkt grafi ve cilt görüntüleri. (Dr. Oğuz Poyanlı'nın arşivinden izni ile alınmıştır.)

görülür. Hastalık daha çok immun sistemi baskılanmış (DM, edinilmiş bağışıklık yetmezliği sendromu, immun sistem baskılayıcı ilaç kullanımı, malnütrisyon ve uzun süreli NSAii [non-steroid anti-enflamatuvar ilaç] kullanımı) kişilerde sıklıkla gözlenir. ${ }^{[7]}$ En sık alt ekstremiteler, karın ve perine bölgesinde görülür. Çoğunlukla sellülitin derin dokulara ilerlemesiyle oluşur. Sistemik bulgular (ateş, halsizlik, üşüme titreme) genellikle vardır. Hasta uykuya eğilimli ve dezoryentedir. ${ }^{[8]}$ Enfeksiyon ajanının cilt altı dokuda yüzeyel ve derin fasyalar boyunca yayılımı sonrası derin dokularda salgıladıkları toksin ve enzimlerle vasküler tıkanıklık oluşturarak doku iskemisi ve nekrozu gelişimine neden olur (Şekil 1). Yüzeyel duyu sinirleride etkilenir ve kutanöz anestezi meydana gelir. ${ }^{[8]}$ Nekrotizan fasiit iki sınıfta incelenmektedir. Tip I polimikrobiyal tiptir. Anaerop bakterilerle birlikte A grubu dışı streptokoklar ve barsak bakterilerinin (Enterobacteriaceae üyesi bakteriler) birlikte oluşturduğu enfeksiyondur. Tip II ise monomikrobiyal tiptir. Etken $A$ grubu $\beta$ hemolitik streptokoklar veya S.aureus'tur. ${ }^{[9]}$

Tanıda nekrotizan fasitten şüphelenmek esastır. Illk bulgular sellülitle benzerdir. Etkilenen bölgede şiddetli ağrı ve toksemi varlığında nekrotizan fasiit açısından değerlendirilmelidir. Yüksek ölüm oranı nedeniyle tedaviye hemen başlanmalıdır. Tedavide tüm cansız dokuların cerrahi debridmanı ve etkene yönelik antibiyoterapi uygulanmalıdır. Antibiyotik olarak kristalize penisilin veya ikinci seçenek olarak klindamisin kullanılabilir. Polimikrobiyal formda gram negatif bakterileride kapsayacak şekilde kombinasyon yapılmalıdır (aminoglikozit veya sefalosporin ile). Ayrıca hiperbarik oksijen tedavisinin de etkinliği vardır. ${ }^{[3,9]}$

\section{Klostridiyal Miyonekroz}

Gazlı gangren olarak da bilinir. Clostridium sını$\mathrm{fl}_{\mathrm{I}}$ bakteriler (C.perfringens, C.novyi, C.histolyticum ve C.septicum) neden olmaktadır. En sık etken C.perfringens'dir. C.septicum'un neden olduğu gazlı gangren \%67-100 oranında ölümcül seyreder. Risk faktörleri arasında malignite, DM, nötropeni, kemoterapötik ilaç kullanımı, radyoterapi ve AIDS (Acquired Immune Deficiency Syndrome; Kazanılmış Bağışıklık Yetersizliği Sendromu) sayılabilir. Çoğunlukla travma sonrası (parçalı kırıklar ve penetran yaralanmalar) başlayan (ilk 24 saat) şiddetli ağrı önemli bir bulgudur. Cilt rengi soluk renkte iken sonraları kahverengi daha sonra mor renk alır. Kötü kokulu akıntı tabloya eşlik eder. Krepitasyon geç dönem bulgusudur. Taşikardi, ateş veya hipotermi, terleme, hipotansiyon, deliryum ve stupor klinik tabloya eşlik eder. Sistemik toksisite bulguları görülür. Septik şok ve çoklu organ yetmezliği hızla gelişir. Kötü prognoz kriteri şok ve hipotermidir. Tedavide tüm ölü dokuların çıkarıldığı ardışık cerrahi debridman, antibiyoterapi ve hiperbarik oksijen tedavisinin zaman kaybetmeden uygulanması 


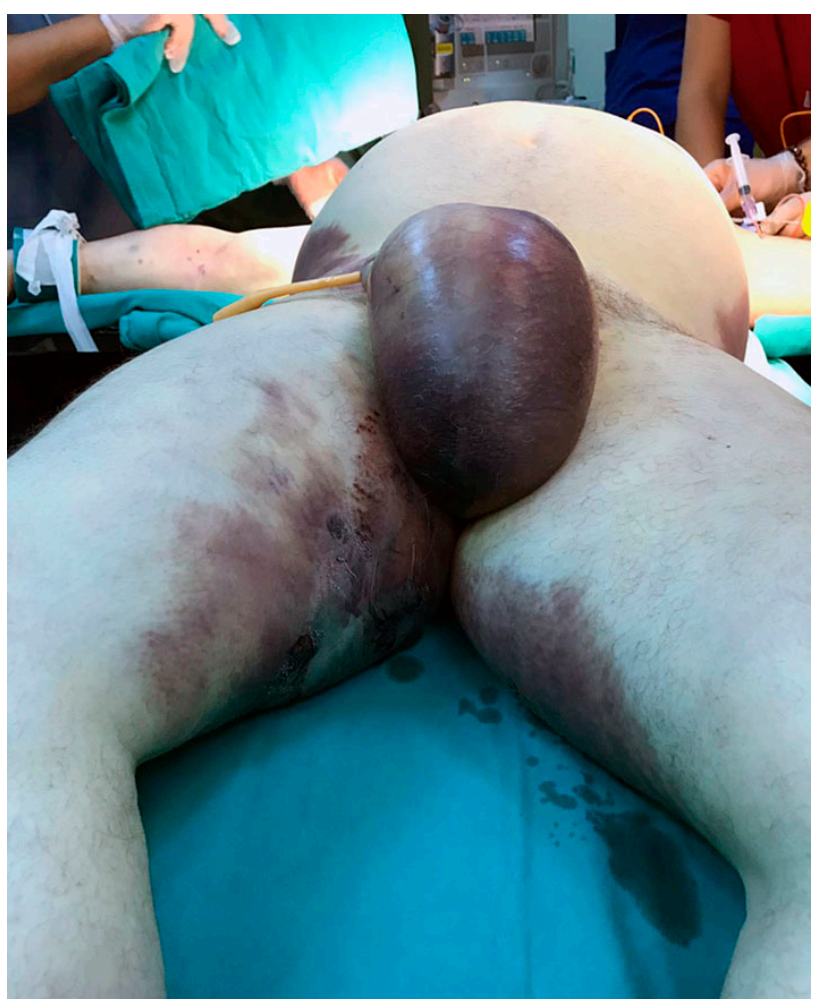

Şekil 2. Fournier gangreni. (Dr. Oğuz Poyanlı'nın arşivinden izni ile alınmıştır.)

esastır. Buna rağmen bazı olgularda amputasyon hayat kurtarıcı olabilir. ${ }^{[5,9]}$

\section{Fournier Gangreni}

Sıklıkla erkeklerde, perine bölgesini tutan ve yüksek mortalite oranları ile seyreden ilerleyici nekrotizan yumuşak doku enfeksiyonudur (Şekil 2). ${ }^{[10]}$ Sadece skrotumda görülebildiği gibi penis, perine karın duvarına kadar yayılım gösterebilir. Genellikle etken polimikrobiyaldir. Aerobik gram negatif bakterilerle anaerop bakteriler sıklıkla etkendir. ${ }^{[11]}$ Enfeksiyon şiddetli ağrıyla başlar. Skrotum ödemli ve koyu mor görünümdedir. Krepitasyon eşlik edebilir. Tedavide acil cerrahi debridman ve antibiyoterapi esastır. ${ }^{[3,5]}$

\section{KAYNAKLAR}

1. Esposito S, Leone S, Petta E, Noviello S, lori I. Skin and soft tissue infections: classification and epidemiology. Infez Med 2009;17(Suppl 4):6-17. https://pdfs.semanticscholar.org/ a738/c3a55143d0ccd0cc9d8c876f6c5a2d944930.pdf

2. Stevens DL, Bisno AL, Chambers HF, Dellinger EP, Goldstein EJ, Gorbach SL, Hirschmann JV, Kaplan SL, Montoya JG, Wade JC; Infectious Diseases Society of America. Practice guidelines for the diagnosis and management of skin and soft tissue infections: 2014 update by the Infectious Diseases Society of America. Clin Infect Dis 2014;59(2):e10-52. Crossref

3. Krasagakis $K$, Valachis A, Maniatakis $P$, Krüger-Krasagakis $\mathrm{S}$, Samonis G, Tosca AD. Analysis of epidemiology, clinical features, and management of erysipelas. Int J Dermatol 2010;49(9):1012-7. Crossref

4. Miller LG, Eisenberg DF, Liu H, Chang CL, Wang Y, Luthra R, Wallace A, Fang C, Singer J, Suaya JA. Incidence of skin and soft tissue infections in ambulatory and inpatient settings, 2005-2010. BMC Infect Dis 2015;15(1):362-70. Crossref

5. Esposito $S$, Bassetti $M$, Borrè $S$, Bouza $E$, Dryden $M$, Fantoni M, Gould IM, Leoncini F, Leone S, Milkovich G, Natwani D, Segreti J, Sganga G, Unal S, Venditti M. Diagnosis and management of skin and soft-tissue infections (SSTI): a literature review and consensus statement on behalf of the Italian Society of Infectious Diseases and International Society of Chemotherapy. J Chemother 2011;23(5):251-62. Crossref

6. EB Chahine, AJ Sucher. Skin and soft tissue infections. PSAP 2015:5-23. https://www.accp.com/docs/bookstore/ psap/2015B1.SampleChapter.pdf

7. Sanchez-Porto A, Martin-Gomez M, Casanova-Roman M, Casas-Ciria J, Nacle B. Necrotizing soft-tissue infections in a general hospital. Infez Med 2010;18(3):191-2. https:// pubmed.ncbi.nlm.nih.gov/20956877/

8. Kihiczak GG, Schwartz RA, Kapila R. Necrotizing fasciitis: a deadly infection. J Eur Acad Dermatol Venereol 2006;20(4):365-9. Crossref

9. Stevens DL, Aldape MJ, Bryant AE. Necrotizing fasciitis, gas gangrene, myositis and myonecrosis. In: Cohen J, Powderly W, Opal S, editors. Infectious Diseases, 3rd ed. USA: Mosby Elsevier; 2010. p.119-27.

10. Bruketa T, Majerovic M, Augustin G. Rectal cancer and Fournier's gangrene -current knowledge and therapeutic options. World J Gastroenterol 2015;21(30):9002-20. Crossref

11. Laor E, Palmer LS, Tolia BM, Reid RE, Winter HI. Outcome prediction in patients with Fournier's Gangrene. J Urol 1995;154:89-92. Crossref 